\title{
A PRIVACIDADE DA PESSOA HUMANA NO AMBIENTE DE TRABALHO
}

\author{
Paulo Eduardo Vieira de Oliveira*
}

\begin{abstract}
Resumo:
O contrato de trabalho não se resume ao pagamento de salário, mediante contraprestação de trabalho, c tem dimensão muito maior do que a patrimonial, envolvendo a dignidade das partes envolvidas. Assim, o empregador deve respeitar o empregado como cidadão, sob pena de ter que indenizá-lo pelo ato ilícito praticado.
\end{abstract}

Palavras-chave: Direitos humanos. Direito do trabalho. Indenização.

\begin{abstract}
:
The labour contract doesn't involve only the payment of wages. The employer has to respect the employee also as a citizen. The article tries to study this point of labour contract.
\end{abstract}

Keywords: Emplnyee's human rights. Payment of damages

\section{Privacidade e cidadania}

O caráter sucessivo do contrato de trabalho com suas diversas fases (précontratual, celebração. execução, extinção e pós-contratual), oferece várias oportunidades para que ocorra violação da privacidade. principalmente no que concerne ao empregado.

Ressalte-se que qualquer violação da privacidade importa, em última análise, em desrespeito à cidadania e à dignidade da pessoa humana, esta protegida por princípio constitucional constante do art. $1^{\circ}$ inciso III da nossa Carta Magna.

Cidadania em sentido estrito, como preleciona Manoel Gonçalves Ferreira Fïlho, é um status ligado ao regime político, podendo-se distinguir três graus: a) o mínimo de que há participação no processo político com possibilidade de acesso aos cargos públicos em geral, mas sem elegibilidade; b) o médio, compreendendo elegibilidade com restrições: c) u máximo: com plena elegibilidade e pleno acesso aos cargos públicos. Em sentido lato. cidadania consiste no direito de usufruir a todos os bens que a sociedade dispõe ou deve dispor para todos e não só para eupátridas, tais como: educação escolar nos diversos níveis, scguridade social (saúde pública, da previdência ou da assistência social).

* Professor Doutor do Departamento de Direito do Trabalho e da Seguridade Social da Faculdade de Direito da Universidade de São Paulo. Juiz titular da $49^{\lrcorner}$Vara do Trabalho de São Paulo. 
Não pode o empregador, pelo simples fato de ter o empregado a ele suhordinado e lhe pagar salários, desrespeitar sua privacidade no ambiente de trabalho ou fora dele, violando-Ihe a intimidade, em nome de um suposto poder de direção.

O princípio básico é: empregado e empregador devem. reciprocamente. em todas as fases do contrato, incluída a preliminar. respeitar direitos e deveres individuais e coletivos elencados no art. $5^{\circ}$ da Constituição Federal, que no seu caput declara: "todos são iguais perante a lei, sem distinção de qualquer natureza, garantindose aos brasilciros e aos estrangeiros residentes no País, a inviolabilidade do direito à vida, à liberdade, à igualdade, à segurança e à propriedade"

Dessa forma, têm empregado e empregador, direito à privacidade, à intimidade, à liberdade de pensamento c expressão, de consciência e crença religiosa, de associação, de acesso a informações e de consciência, de convicção política ou filosófica, além de outras.

Dentre as variadas formas que podem propiciar a ofensa aos mencionados direitos de cidadania, duas ofensa ao direito à intimidade e discriminação merecerão análise mais detalhada.

\section{Direito à intimidade}

$\mathrm{Na}$ abordagem da matéria, os autores distinguem os conceitos de intimidade e privacidade nos âmbitos objetivo e subjetivo.

"O direito à intimidade há muito vem sendo conceituado como aquele que visa a resguardar as pessoas dos sentidos alheios, principalmente da vista e dos ouvidos de outrem, pressupõe ingerência na esfera intima da pessoa através de espionagem e divulyação de fatos intimos obtidos ilicitamente"

O conceito objetivo é a "pretensão de um individuo, grupo ou instituição de determinar-se por si mesmo, quando, como e em que, pode comunicar-se a outros, informação sobre ele" e o objetivo "a usfera inderrogável de liberdade pessoal em que se desenvolvem a racionalidade e a vida privada dos individuos"

$\mathrm{O}$ art. $5^{\circ}$, da Constituição Federal, de 1988, explicita três modalidades de inviolabilidade que merecem menção: a intimidade individual (inciso X), a da casa como asilo individual (inciso XI) e da correspondência, das comunicações telegráficas e telefônicas (incisu XII).

Sem forçar a compreensão dos termos, pode-se dizer, que a norma garante três modalidades de intimidades: a individual, a da moradia e a das comunicações.

A Consolidação das I eis do Trabalho é omissa a respeito da questão. 
O Estatuto do Trabalhador Espanhol é mais explícito no que concerne à intimidade, na Lei n. 03/1989, onde se estipula:

Art. $4^{\circ}, 2^{\circ}$ e. Tin la relación de trabajo los trabajadores tienen derecho (...) al respeto de su intimidad y a la consideración debida a su dignidad, comprendida la protección frente a ofensas verbales o físicas de naturaleza sexual.

$\mathrm{O}$ art. 18 do mesmo ordenamento jurídico espanhol ainda dispõe:

Art. 18. Sólo podrán realizarse registros sobre la persona del trabajador, en sus taquilas y efectos particulares, cuando sean necesarios para la protección del patrimonio empresarial y de los demás trabajadores de la empresa. dentro del centro del trabajo y en horas de trabajo. En su realización se respetará al máximo la dignidad e intimidad del trabajador y se contará con la asistencia de un representante legal de los trabajadores o, en su ausencia del centro del trabajo, de otro trabajador de la empresa, siempre que ello fora posible.

Em diversas ocasiões, no curso de uma relação de emprego, uma das partes pode praticar atos que agridam as intimidades apontadas.

O trabalho doméstico, certamente mais do que qualquer outro, propicia a violação da moradia, quer porque freqüentemente o empregado mora em cômodos da casa em que trabalha, cômodos que podem ser facilmente vasculhados, quer porque o trabalho da empregada lhe dá acesso direto a todos os compartimentos.

Algumas funções desenvolvidas no interior do estabelecimento do empregador, como a de telefonista, por exemplo. possibilitam um contato com a correspondência telegráfica e telefônica do empregado e do empregador, propiciando uma violação. Embora funcionalmente tais empregados tenham acesso às informações confidenciais, a violação ocorrerá, quando estes as revelarem a terceiros.

Há uma grande incidência, que se revela nas decisões judiciais, da violação da intimidade individual no âmbito do estabelecimento, explicando-se porque os autores costumam dar a esta maior atenção enfocando, sobretudo, aquela cometida pelo empregador contra seu empregado, embora, a de ambas as partes, devam ser resguardadas.

No entanto, certas asserções que se fazem ao direito à intimidade individual do empregado, em outros contextos e circunstâncias, valem, também, em relação à do empregador. 
Falar em intimidade, não do empregador ou de seus prepostos como pessoas físicas, mas da empresa pessoa jurídica pode ser exagero. Todavia, quando se estuda a figura do ato faltoso da revelação de segredo por parte do emprugado, pode-se dizer que houve a violação de uma certa "intimidade" conhecida como a "alma do negócio" Entende-se por segredo. "todo fato, ato, ou coisa, que, de uso ou conhecimento exclusivo da empresa, não possa ou não deva ser tornado público, sob pena de causar um prejuízo, remoto, imedialo ou provável, àquela"

Observa ainda Dorval de Lacerda, que o ato faltoso consiste em violar, não implicando necessariamente revelar: e para justificar o dever de sigilo, diz o mesmo fundar-se no dever de fidelidade.

O direito à intimidade e o à privacidade podem ser classificados como direitos individuais, relativamente à liberdade, com natureza jurídica de dircito fundamental de defesa.

Como já sc sublinhou muito bem:

\begin{abstract}
A subordinação não significa sujeição ou submissão pessoal. Este conceito corresponde a etapa histórica já ultrapassada e faz lumbrar lutas politicas que remontam à condição do trabalhador como objeto de locatio, portanto equiparado a coisa (res). U trabalhador como pessoa, não pode ser confundido com a atividade, esta sim, objeto da relação juridica. No dizer de Francisco Ferrara, essa luta. que se vinculava a formas econômicas anacrônicas e superadas. não existe como antes e está desaparecendo paulatinamente para dar espaço à idéia de coordenação negociada de atividades profissionais com vistas ao cumprimento de iniludiveis fins comunitários.
\end{abstract}

Costuma-se apresentar a subordinação como o lado passivo do puder diretivo do empregador. Este poder, em relação a seus trabalhadores, pode se manifestar em três modalidades que se concatenam: o de organização (dar conteúdo concreto às atividades a serem desenvolvidas pelo trabalhador), o de controle (verificar a observância das ordens c orientações dadas) e o disciplinar (punir por inadimplemento das ordens).

É o exercício do poder diretivo do empregador que mais freqüentemente, como demonstram reiteradas decisões judiciais, vem propiciando ocasiões de invasão da privacidade e da intimidade do operário.

Entende-se, assim, porque os autores relacionam violação da intimidade $e$ privacidade com o poder diretivo.

Neste sentido, merece citação a obscrvação de Alice Monteiro de Barros, 
Não é o fato de um empregado encontrar-se subordinado ao empregador ou de deter este último o poder diretivo que irá justificar a ineficácia da tutela ḋ intimidade no local de trabalho. do contrário. haveria degeneração da subordinação juridica em um estado de sujeição do empregado. O contrato de trabalho não poderá constituir "um título legitimador de recortes no exercício dos direitos fundamentais" assegurados ao empregado como cidadão; essa condição não deverá ser afetada quando o empregado se inserc no organismo empresarial, admitindo-se, apenas, sejam modulados os direitos funclamentais na medida imprescindivel do correto desenvolvimento da atividade produtiva.

Pode-se, alinal, tecer breves considerações entre direito à intimidade e à honra porque, como nota Aparecida I. Amarante, já faz tempo que se aceitou o direito à honra como integrante do núcleo da privacidade. Hoje este entendimento está superado:

Se a honra, conforme anotamos, significa a dignidade pessoal reflutida na considuração dos outros ¿ no sentimento da própria pessoa, a intimidade, em sentido oposto, quer justamente significar a subtração da consideração de terceiros, da publicidade e permanência tranqüilidade (...) Por que não se confundiram os mencionadus direitos é que se verifica uma ofensa à honra, sem que atinja a intimidade uu vice-versa, bem como se comprova lesão a ambas concomitantemente" (...) Quando a lcsão individual, por indiscrição, compromete a dignidade de alguém, estamos diante da ofensa à honra: quando. porém, a lesão atinge apenas o mencionado resguardo. há ataque à intimidade. Por fim, os ataques à honra tanto recaem na vida privada quanto pública do indivíduo, diferentemente dos ataques à intimidade.

Em sintese, configurada a violação das três intimidades do individuo, a da casa, das comunicações telefônicas c telegráficas, ocone dano, cujo ressarcimento pode ser requerido através de ação especifica.

\section{Discriminação c ação afirmativa}

A importância do estudo da discriminação no presente artigo reside no fato de que sua ocorrència pode gerar situações que levem à violação da privacidade da pessoa humana no ambiente de trabalho.

A tutela antidiscriminatória está inserida nos arts. $5^{\circ}$ inciso XLI, e $7^{\circ}$, inciso XXX da Constituição Federal, de 1988.

A esse respeito, observa Alice Monteiro de Barros: 
U principio da não-discriminação possui concxão com a garantia dos direitos da personalidade e atua como limite imposto pela Constituição Federal à autonomia do empregador, quando da obtenção de dados a respeito do candidato ao emprego, e se projeta durante a execução do contrato.

Para melhor entendimento do tema, cabe, inicialmente, diferenciar discriminação e ação afirmativa:

Discriminação consiste em privar alguém de algo que os cidadãos, em geral. têm direito. A Convenção 111 da Organização Internacional do Trabalho, OIT, sobre a discriminação em matéria de emprego e ocupação, de 1958, ratificada pelo Brasil, assim define discriminação:

Art. $1^{\circ}(\ldots)$.

a) Toda distinção, exclusão ou preferência baseada $\mathrm{em}$ motivos de raça, cor, sexo, religião, opinião pulítica. ascendência nacional ou origem social que tenha como efeito anular ou alterar igualdade de oportunidades ou de tratamento e no emprego ou na ocupação.

b) Qualquer distinção, exclusão, preferência que tenha como efeito alterar a igualdade de oportunidades ou de tratamento no emprego ou ocupação.

Todavia, não são consideradas como discriminação as distinções ou exclusões baseadas em qualificações exigidas para determinado emprego (Art. $1^{\circ}$, parágrafos $1^{\circ}, 2^{\circ}$ e $3^{\circ}$ ).

Há, inegavelmente. da parte do empregador maior possibilidade de discriminar a partir da fase precontratual e em toda a vigência do contrato.

$\mathrm{Na}$ ação afirmativa o direito leva em consideração situações concretas e permite que se dêem maiores oportunidades a certas pessoas em condições especiais, porque em se tratando de justiça distributiva, que visa equiparar, não se ferem normas de direito dando mais a quem tem menos.

$\mathrm{O}$ art. $5^{\circ}$, parágrafo $2^{\circ}$ da mesma Convenção 111 , explicita não serem discriminatórias as medidas especiais de proteção destinadas a atender necessidades particulares de pessoas que, por razão de sexo, idade. invalide $z$, encargos familiares, nivel social ou cultural, tenham necessidade de proteção ou assistência especial.

Exemplos de disposições prevendo "ação afirmativa" encontram-se na Constituição Federal que assegura "proteção do mercado de trabalho da mulher. mediante incentivos específicos, nos termos da lei" (art. $7^{\circ}$, inciso XX), ou em favor do deficiente (art. 37, inciso VIIl e leis ordinárias que lhe reservam percentuais na admissão). 
O parágrafo único do art. 373-A da CLT, dispõe não-ferir o princípio da não discriminação "medidas temporárias que visem ao estabelecimento das políticas de igualdade entre homens e mulheres, em particular as que se destinem a corrigir as distorções que afetam a formação profissional, o acesso ao emprego e as condições gerais de trabalho da mulher"

A maioria, se não a totalidade, das normas de proteção da maternidade são disposições de "ação afirmativa"

4. Obrigação de não-discriminar

Dentre as múltiplas modalidades de ofensa à cidadania e à privacidade que podem ocorrer em uma relação de emprego, destaca-se a discriminação que as partes podem sofrer em todas as fases do contrato de trabalho. Embora, por razões óbvias, se aborde a discriminação que possa sofrer o empregado, a obrigação de não exercê-la, é de ambas as partes da relação empregatícia.

Abordar-se-á, a seguir, algumas das inúmeras possibilidades de ocorrência de discriminação, em virtude de gênero, homossexualidade, maternidade, idade, etnia, estado civil, ideologia, nacionalidade, saúde e vida pregressa trabalhista, ensejadoras de danos pessoais.

\subsection{Gênero}

Textos legais, doutrinários e de decisões judiciais, habitualmente utilizam o termo "sexo", referindo-se a ambos, feminino e masculino. O termo mais adequado é "gênero"

Tratando-se de discriminação pode ser atingido o homem e a mulher, mas o fato desta ter sofrido e ainda sofrer, maior discriminação no mundo do trabalho, no que se refere ao acesso a ele, à remuneração e às funções mais graduadas, faz com que as atenções se voltem para a sua exclusão. Assim, sem nenhum paradoxo. a oferta de trabalho exclusivamente para mulheres com explícito afastamento do homem, pode visar a mão-de-obra mais barata.

Em rigor, não há trabalhos "masculinos" e "femininos" a procura maior por determinadas funções, por parte dos homens (motoristas de caminhões ou de táxis, por ex.) e das mulheres (enfermagem, serviço social, etc), reflete resquícios de preconceitos, ou, na melhor das hipóteses, uma tendência cultural para determinados afazeres que seriam mais adequados à psicologia masculina ou feminina. 
O empregador tem amplo poder de estabelecer a política de empregos, mas nesta não pode ser incluída a discriminação à base do gênero, sob pena de configurar-se dano moral ressarcivel.

Razões históricas fizeram e fazem com que o legislador estipule normas diferenciadas de proteção ao trabalho da mulher, muitas das quais ainda refletem situações novecentistas, quando a criança, o adolescente e a mulher, eram considerados "meias forças" a quem, "coetcris puribus" se afirmava explicitamente (talvez de modo não tanto hipócrita como hoje), caber menor remuneração pelo mesmo trabalho.

As normas anteriores de "proteção" à mulher, tidas no passado como de ação afirmativa, acabaram tendo efeito contraproducente e se tornaram de discriminação negativa, o que levou o legislador a suprimir várias proibições, fato que se verifica no confronto de antigas e atuais normas da CL.T. Houve, por exemplo, tempo em que o princípio era o da proibição do trabalho noturno, especificando-se as exceções; depois, prevaleceu o princípio da permissão. especificando-se as exceções.

A partir da Constituição, de 1988, entendeu-se que as restrições não se justificavam, razão pela qual, a Lei n. 7.855/89, suprimiu. sem sistematizar, várias proteções.

Visando especialmente ao trabalho da mulher, o art. 373-A, relaciona e proíbe os atos discriminatórios: publicar e fazer publicar anúncio no qual haja referência ao sexo, recusar emprego, promoção ou motivar dispensa do traballho em razão de sexo, considerar o sexo como variável, determinante para fins de remuneração e formação profissional, impedir acesso ou adotar critérios subjetivos para deferimento de inscrição ou aprovação em concursos em razão de sexo.

O contexto em que se situa a norma citada, não deixa dúvidas, que se visa a proteção do trabalho da mulher. tecnicamente, porém, os mesmos atos apontados podem configurar-se, em determinadas situações, como discriminatórios contra o homem.

No inciso I do art. 373-A, abre-se uma exceção quanto à publicação de anúncio, "salvo quando a natureza da atividade seja notória e publicamente incompatível" A matéria implica complexidade, uma vez que é indispensável a verificação de quais trabalhos, por sua natureza seriam notoriamente incompativeis.

Há ordenamentos jurídicos em que, por exemplo, se proíbem determinadas atividades insalubres para a mulher, não porque só afetem o organismo procriador feminino, mas porque (ao que consta. cientifica mas não dogmaticamente comprovado) têm efeitos que se prorrogam no tempo prejudicando no futuro o feto.

É evidente, que a opção por ter filhos é individual da cada mulher. na hipótese. o direito proíbe, levando em consideração que uma grande maioria faz esta 
upção, portanto, a proteção seria não contra o trabalho da mulhır, mas de uma maternidade potencial. O tema sempre abre espaço para acaloradas discussões e há quem veja, em tais formulações, um machismo oculto nada sutil ou uma visão da mulher apunas como "reprodutora da espécic"

Qualquer discriminação fundada ım gênero implica em violação da privacidade que pode ser reparada por ação pleiteando a indenização pelo dano pessoal.

\subsection{Homossexualidade}

Durante anos, o fenômeno da homossexualidade, de pouca expressão quantitativa, foi objeto de uma rejeição cultural muito forte, sobretudo, quando fundamentada cm motivos religiosos. Hoje se tem notícia de que está presente nos mais diversos meios sociais, em alguns dos quais como, por exemplo, nas fileiras das forças armadas que pareciam fortalezas inexpugnáveis.

Indubitavelmente, os homossexuais constituem-se minoria. Os grupos minoritários, de qualquer coloração ideológica, costumam ser mais agressivos em suas reivindicações para conseguir espaço na sociedade.

Não há yualquer razão que justifique a exclusão de homossexuais do mercado de trabalho.

Se o empregador indagar ao candidato sobre suas preferências sexuais, este tem todo o direito de omiti-las ou ocultá-las, caso entenda necessário, uma vez que se trata de opção individual situada na esfera da intimidade.

Sobre o tuma, assim expõe, Alice Monteiro de Barros:

Quando o preceito constitucional veda a discriminação no ato da admissão do empregado e considera invioláveis sua intimidade c sua vida privada, está protegendo uma sírie de direitos e liberdades individuais. $E$, em conscqüência estabelece um limite ao poder empresarial de questionar sobre os modos pelos quais o empregado conduy sua vida privada, dentre eles, fatos ligados à libcrdade pessoal. Logo, a proibição de indagar é uma conseqüîncia da própria idéia de tutela à privacidade (...).

Assim sendo, não pode o empregador em qualquer das fases do contrato de trabalho, discriminar o empregado em virtude de sua condição de homossexual, mormente quando este desenvolve suas atividades lahorais de maneira recatada. Quando o tema é objeto de seminários acadêmicos, há quem aponte certos comportamentos estranhos. de homossexuais. O decoro que o empregador pede de todo c qualquer 
empregado, é exigível, também, do homossexual. Configurada a discriminação, ocorre o dano pessoal, ressarcivel.

\subsection{Maternidade}

$O$ art. 391 da CLT estipula que o fato de a mulher ter-se casado ou se encontrar em estado de gravidez, não constituem motivos para a rescisão de seu contrato de trabalho e, seu parágrafo único, proíbe que regulamentos, convençõus coletivas ou contratos de trabalho, restrinjam o direito da mulher ao emprego por tais motivos.

O Direito francês em seu Código do Trabalho, enuncia um princípio de proteção, que merece ser lembrado:

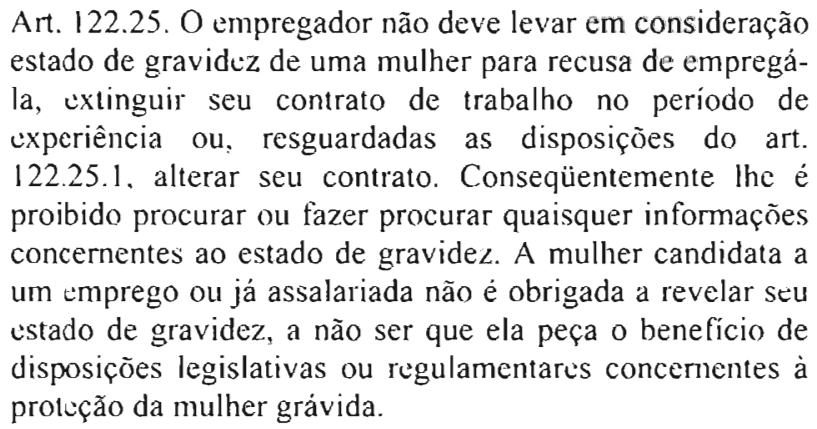

Lisse tipo de discriminação é bastante comum e se manifesta dia a dia, através de diversas práticas, como a exigência de exames prévios de não-gravidez ou de esterilização, em que pese mesmo a vedação legal para que isso ocorra.

Não se pode exigir atestado ou exame para o fim de verificação de gravidez e, muito menos, que o médico transmita ao empregador qualquer informação nesse sentido, limitando-se, a dizer se aquela candidata encontra-se ou não, apta para a função a qual se destina.

Ressalte-se, por oportuno, que a candidata ao emprego ou empregada (conforme o caso). tem plena possibilidade de ocultar seu estado gravídico, não importando tal comportamento em violação ao princípio da boa-fé, mas apenas e tão somente restrição quanto à sua intimidadc.

Veja-sc, a título de exemplo, decisão de um tribunal alemão a respeito da questão:

A autora começou a trabalhar no dia 2 de novembro de 1981. após uma entrevista com o empregador uns dias antes. Na entrevista foi-lhe perguntado se estava grávida, o que foi respondido negativamente. No dia 3 de novembro 
ela apresentou um atestado médico certificando que estava grávida de dez scmanas. No mesmo dia o empregador contustou a validade do contrato de trabalho e a despediu.

O tribunal pronunciou-se a favor da trabalhadura. entendendo que o empregador não tinha o direito de the perguntar se estava grávida. Mesmo reconhecendo que houve mentira deliberada, esta não era causa de anulação do contrato, a menos que se tratasse de função proibida às mulheres grávidas. Em virtude do art. 66I, letra "a" 1.1 do Código Civil, o empregador não pode praticar discriminação na formação de um contrato. Pedir a uma candidata para dizer se ela está grávida indicava que o empregador ia contratá-la, ou não, para assumir as obrigaçóes que decorrem do emprego de uma mulher em tal situação. O artigo 661, letra "a" do Código Civil visa a evitar que considerações desta natureza sejam levadas em consideração, quando do engajamento do trabalhador. Permitir ao empregador interrogar as candidatas quanto a eveniual gravidez as obrigaria a revelar fatos que diminuiriam suas possibilidades de serem tratadas em pé de igualdade com os candidatos homens para obter o emprego. Esta pergunta é incompativel com as disposições do art. 661. letra " $a$ " do Código Civil, exceto no que concerne a funções que são proibidas às mulheres grávidas.

Este acórdão traz uma lição que merece comentários: verifica-sc que toda indagação que invade a privacidade, pode ser repelida. Quem não tem direito de perguntar, não tem direito a uma resposta, que exponha uma "verdade" que se quer ocultar.

A ocultação da verdade acontece freqüentemente na vida social, mesmo em ocasiões onde não se trata de invasão de privacidade; o esmoler abordado por um pedinte responde não ter dinheiro, embora, de fato, o tenha.

Ressalva pode ser feita, àquelas situações em que a gravidez constitua obstáculo ao excrcício das funções e realização das tarcfas quando, então, a mulher não pode ocultar seu verdadeiro estado, como é o caso do labor em usinas nucleares ou clínicas radiológicas, uma vez que em tais situações a radiação é fator teratogênico, podendo causar a malformação do féto.

A Lei n. 9.029/95 vai mais longe, tipificando como crimes, as seguintes práticas: exigência de teste, exame. perícia, laudo, atestado, declaração ou qualquer outro procedimento relativo à esterilização ou estado de gravidez; a adoção de quaisquer medidas, de iniciativa do empregador, que configurem indução ou instigação à esterilização genética. 
Cabe, ainda, salientar que, se a mulher, empregada ou candidata ao emprego, for obrigada a submeter-se a exame laboratorial que ateste sua condição de "não-grávida" estará configurada a prática de crime por parte do empregador, além de estar a empresa violando o direito de intimidade, podendo ser condenada a pagar indenização pelo dano pessoal causado.

A pena estipulada para u crime. é de um a dois anos de detenção, além da multa administrativa, em valor correspondente a 10 (dez) vezes o maior salário pago pelo empregador, elevado em $50 \%$ na hipótese de reincidência e a proibição de obter empréstimo ou financiamento em instituições financeiras oficiais.

Ainda nesse sentido, relata, Alice Monteiro de Barros:

A Procuradoria do Trabalho da $3^{\circ}$ Região, considerando o expediente encaminhado pelo Chefe da Divisão de Segurança e Saúde du Trabalhador, no qual dá noticia da exigência de teste de gravidez pela empresa Katrin Têxtil e Confeç̧ões Ltda., instaurou inquérito civil público para apuração do fato (...). A referida empresa firmou termo de compromisso perante o Ministério Público. comprometendo-se a não estabelecer quaisquer procedimentos discriminatórios contra a mulher no ato de admissão. ficando claro que não poderá exigir teste de gravidez para as candidatas a emprego. sob pena de incidir em multa de R\$ $100.000,00$ por trabalhadora discriminada.

\subsection{Idade}

A discriminação de um candidato por motivo de idade (salvo se esta for exigida em decorrência do cargo a ser ocupado), implica em prática de ato ilícito pelo empregador, ensejador de dano pessoal reparável.

Sabe-se que há uma discriminação negativa em relação às pessoas idosas; um problema que pode se agravar na medida em que cresce o número de idosos no Brasil.

A regra geral é que a pessoa com mais de 45 (quarenta e cinco) anos tenha grande dificuldade de colocação no mercado de trabalho, situação que se agrava, quanto menos técnica for a função procurada.

F.m relação ao adoluscente, há norma de discriminação positiva impedindo que seja admitido em trabalhos insalubres, inseguros (perigosos) e penosos. Estudos da O.M.S. - Organização Mundial da Saúde, mostram, que o organismo do adolescente é mais susceptivel aos efeitos nocivos dos elementos insalubres. 
De qualquer forma, qualquer discriminação fundada em idade deve ser reprimida, independentemente de que fase do contrato de trabalho esta ocorrer.

\subsection{Finia}

A etnia caracteriza-se como um grupo social, cuja identidade se define pela comunidade de lingua, cultura, tradições, monumentos históricos e território.

Falar a mesma lingua, estar radicado no mesmo ambiente humano, no musmo território e possuir as mesmas tradições, são fatorıs que constituem a base fundamental das relações ordinárias da vida cotidiana. Marcam tão profundamente a experiência dos individuos, que se transformam num dos elementos constitutivos da sua personalidade e definem, ao mesmo tempo, o caráter específico do modo de viver de uma população.

Há uma discriminação difusa contra o negro no Brasil, que se verifica pelo pequeno indice de negros existentes na magistratura, nos postos de comando das forças armadas, nas faculdades de medicina, pelos papéis que se lhes atribuem nas novelas e peças teatrais (domésticas, serviçais), etc.

Tais fatos surgem como resquícios do colonialismo c podem ocorrer como efeito de uma discriminação maior, fruto da marginalidade social do negro, que tem mais dificuldade de beneficiar-se dos meios que the permitem a ascensão social.

Assim, quando um candidato deixa de ser admitido em virtude de cor e tal motivo se torna manifesto, o empregador, inequivocamente, incide na prática de dano pessoal, sem mencionar-se os aspectos penais decorrentes.

\subsection{Estado civil}

O estado civil é uma circunstância que não atèta as relações de trabalho.

A Constituição de 1988 proíbe expressamente em seu art. $7^{\circ}$, inciso XXX, a diferença no critério de admissão por motivo de estado civil.

Entre nós, os questionários que se dão aos candidatos, revelam imediatamente seu estado civil. A rigor, a mulher ou o homem, podem não decliná-lo. Qualquer declaração não verdadeira da candidata (ou candidato), sobre seu estado civil, não a compromete com o empregador (hipótese de casamento secreto, por exemplo).

A discriminação quanto ao estado civil, atinge principalmente a mulher casada (ou que pretenda se casar), por causa das normas de proteção à maternidade.

Indagações à mulher ou ao homem, sobre se estes pretendem casar-se, tambím não precisam ser respondidas pelos candidatos e se o forem. não podem se 
constituir em motivo de recusa da contratação, sob pena de violação de sua intimidade, enscjadora de dano pessoal ressarcivel, a não ser que, a qualquer título, estes queiram beneficiar-se da condição de casados.

\subsection{Ideologia}

Norberto Bobbio, face a gama de significados que são atribuidos ao termo ideologia, divide-os entre significado forte e significado fraco:

No seu significado fraco, Ideologia designa o genus. ou a species diversamente definida, dos sistemas de crenças políticas: um conjunto de idéias e de valores respeitantes à ordem pública e tendo como função orientar os comportamentos politicos coletivos. O significado forte tem origem no conceito de Ideologia de Marx, entendido como falsa consciência das relações de dominio entre as classes, e se diferencia claramente do primeiro porque mantém, no próprio centro, diversamente modificada, corrigida ou alterada pelos vários autores, a noção de falsidade: a ldeologia é uma crença falsa. No sentido fraco, Ideologia é um conceito neutro, que prescinde do caráter eventual e mistificante das crenças politicas. No significado forte, Ideologia é um conceito negativo que denota precisamente o caráter mistificante da falsa consciência de uma crença politica. Na ciência e na sociologia politica coniemporânea, predomina nitidamente o significado fraco de Ideologia, tanto na acepção geral quanto na particular.

Os incisos IV, VI, VIIl e XVIl do art. $5^{\circ}$ da Constituição Federal, proíbem a ocorrência de discriminação por motivo ideológico, que se concretiza em crença religiosa ou de convicção fillosófica ou política.

Existem precedentes jurisprudenciais determinando a reintegração de empregado despedido por motivo de perseguição ideológica, conforme transcreve Alice Monteiro de Barros, in verbis:

Despedida por justa causa. Nulidade. Motivação política. Perseguição ideológica. O empregador, para exercer o direito de resolver o contrato por falta grave do empregado, cinge-se às hipóteses elencadas no art. $482 \mathrm{da} \mathrm{CLT.} \mathrm{Se}$ empresa pública, adicione-se a necessária obediência aos principios da legalidade e da impessoalidade, dentre outros, por força do art. 37. caput, da CF/88. Ao comprovar-se que a despedida do empregado deu-se por perseguição políticopartidária - em autêntica restrição ao princípio de liberdade de expressão, garantido pelo artigo $5^{\circ}$, inciso IV da $\mathrm{CF} / 88$ - 
finda, ainda, o empregador por ferir o principio da impessoalidade, pois o ato resilitório deixa de atender ao interesse público para satisfazer sentimentos pessoais. Por sua vez, a violação ao principio da legalidade dá-se pela ultrapassagem dos limites em que, permitido o exercicio do ato demissório, eis que, no caso vertente, tem traço eminentemente vinculado.

(Ac. TRT $9^{a}$ Região, $3^{a}$ T., RO 00433/93, Rela Juíza Wanda Santi Cardoso da Silva, DJPR 8.7.94, p. 61, Dicionário de Decisões Trabalhistas, Calheiros Bonfim, $25^{*}$ edição).

O texto constitucional garante a intimidade do individuo, não permitindo intromissão na vida privada do empregado, preservando a liberdade ideológica, esta, portanto, não pode ser motivo de exclusão.

Poder-se-ia indagar, se alguém, cuja ideologia não se sintonize com a filosofia do futuro empregador, poderia, por esse motivo, ser excluido?

A matéria assume complexidade, quando se trata de função que $o$ candidato ao emprego. tem posições ideológicas que o colocam em confronto direto com a mundividência do tomador de serviço. Isso pode ocorrer e tem-se notícia que ocorreu com um "jornalista âncora" de um telejornal. Irrelevante a circunstância, que o caso que se tem notícia tenha ocorrido na oportunidade em que uma estação de televisão teve sua propriedade mudada, o que resultou numa total incompatibilidade da filosofia do "âncora" com a dos novos proprietários.

Ocorre exorbitância, quando a função não interfere na ideologia (por exemplo, cozinheiro, porteiro, pedreiro etc). hipóteses em que a exclusão pode configurar-se discriminação. Todavia, o tomador de serviços pode exigir que o candidato, resguardadas suas conviç̧ões pessoais, respeite, no serviço a orientação que a entidade dá a seus adeptos.

$\mathrm{Na}$ formação do contrato de trabalho estas circunstâncias podem ser levadas em consideração, porque. efetuado o contrato. a complexidade é maior e o despedimento pode não ser juridicamente justifícável.

Assim sendo, mostra-se inviável a discriminação de empregado (especialmente daquele exercente de cargo não qualificado), por motivo de ideologia e sua ocorrência, configura-sc como hipótese de dano pessoal indenizávèl.

\subsection{Saúde}

O tema da invasão da privacidade no ambiente de trahalho em razão de problemas de saúde é complexo e pode assumir diferentes conotações. 
Aqui, impõe-se, tratar do problema da mediação do médico em relação ao empregado-paciente e ao empregador.

a) Ética médica nos exames

Existem diversas medidas preventivas de medicina do trabalho visando a saúde e o bem-estar dos empregados no ambiente laboral.

A CLT, em seu artigol68, assim determina:

Art. 168. Scrá obrigatório exame médico, por conta do empregador, nas condições estabelecidas neste artigo e nas insıruções complementares a serem expedidas pelo Ministério do Trabalho:

I - na admissão:

II - na demissão;

III - periodicamente.

Parágrafo $I^{\circ}(\ldots)$.

O empregado ıstá obrigado a submeter-se aos exames médicos descritos nos incisos I, II e III do art. 168 da CLT, mesmo que não scja essa sua vontade, ficando, porém, resguardada sua intimidade.

O parágrafo $5^{\circ}$ do mesmo art. 168 da CLT, com redação dada pela Lei $n$. 7.855/89. determina que o resultado do exame médico será comunicado ao empregado, observados os preceitos da ética médica.

Distinção relevante deve ser feita entre médico empregado e médico não empregado.

Quanto ao múdico não empregado. inexistem grandes problemas, por tratar-se de profissional libcral. O mesmo não ocorre, porém, com relação ao médico empregado. Este, em razão da subordinação existente na relação de emprego, poderia ver-se pressionado a aceitar de seu empregador determinação de não-admissão de empregados portadores de HIV positivo, hipertensão ou empregadas grávidas.

Em qualquer hipótese, o médico, empregado ou não. deve pautar-se pela correta aplicação da medicina e do Código de Ética Médica. que assim dispõe:

Art. II O médico deve manter sigilo quanto às informações confidenciais que tiver conhecimento no desempenho de suas funções. O mesino se aplica ao trabalho em empresas, exceto nos casos em que seu silêncio prejudique ou ponha em risco a saúde do trabalhador ou da comunidade; 
É vedado ao médico:

Art. 102 Revelar fato de que tenha conhecimento em virtude do exercício de sua profissão, salvo por justa causa, dever legal ou autorização expressa do paciente (...);

Art. 105 Ruvelar informações confidenciais obtidas quando do exame mídico de trabalhadores. inclusive por exigência dos dirigentes de empresas ou instituições, salvo se o silêncio puser em risco a saúde dos empregados ou da comunidade:

Art 108 Facilitar manuscio e conhecimento dos prontuários, papeletas e demais folhas de observações médicas sujeitas ao segredo profissionil, por pessoas não obrigadas ao mesmo compromisso.

Conclui-se, assim, pelos dispositivos acima transcritos que, após realizado o exame (seja ele admissional, periódico demissional ou outro, dentro da empresa), o médico não poderá revelar a ninguém (inclusive empregador, departamento pessoal, etc.), o resultado dos mesmos, limitando-se a afirmar se o candidato ou empregado está ou não apto para a função a que se destina.

Isto se dá, porque as informações que os pacientes fornecem quando de seu atendimento médico, assim como, o resultado dos exames e procedimentos realizados com finalidade diagnóstica ou terapêutica, são de sua propriedade.

Alice Monteiro de Barros, em estudo sobre o tema, esclarece:

O Conselho Federal de Medicina, atravís da Resolução n. I.359/92, após prever a obrigatoriedade de os médicos atenderem os pacientes portadores do HIV. assevera estarem esses profissionais, quando prestam serviços à empresa. proibidos de revelar ao empregador o diagnóstico de empregado ou candidato a emprego, cabendo-lhe informar, exclusivamente, quanto à capacidade ou não de exercer determinada função (art. $3^{\circ}$ da Resolução n. 1.359 , publicada no DOU de 19.11.1992).

Os médicos, enfermeiros e demais profissionais de saúde e administrativos, que entram em contato com as informações constantes do prontuário do paciente, têm apınas autorização para ter acesso às mesmas em função de sua necessidade profissional, mas não tîm o direito de divulgá-las.

A garantia do sigilo das informações, alím de uma obrigação legal contida no código penal e no código de ética profissional. é dever de todos os profissionais da área de saúde e também do cmp:egador. 
Assim, o médico não pode, sem o consentimento do empregado, divulgar resultados de exames médicos realizados por qualcuer motivo, sob pena de violar a privacidade de tal empregado.

Se por outras vias, qué não a do médico, o resultado do exame efetuado pelu empregado chegar ao conhecimento do empregador, ainda assim. este não tem o direito de divulgá-lo. sob pena de causar dano pessoal ao empregado.

Portanto, ao médico cabe dizer. unicamente, se o candidato está apto para o exercício da função à qual se destina. se o empregado pode continuar trabalhando naquela função ou, ainda, se é portador de moléstia profissional, nada mais.

Pode-se apontar duas formas de rompimento do sigilo por parte do médico: a exceção ao sigilo e a quebra de privacidade ou de confidencialidade.

A exceção ao sigilo ocorre, quando por força de legislação existente e por justa causa, um profissional é obrigado a comunicar informações sigilosas a que teve acesso em função de sua atividade (maus tratos em crianças e adolescentes, abuso de cônjuge ou idoso, etc).

A quebra de privacidade ou de confidencialidade é a ação de revelar ou deixar revelar informações recebidas em confiança do paciente. Tal hipótese somente é admissível quando: a) um sério dano físico, a uma pessoa identificável e específica. tiver alta probabilidade de ocorrência; b) um benefício real resultar dessa quebra de confidencialidade: c) for o último recurso, após ter sido utilizada persuasão ou outras abordagens e d) este procedimento deve ser generalizável, sendo novamente utilizado em outra situação, com as mesmas características, independentemente de quem seja a pessoa envolvida.

Ressalte-se, ainda, quc o médico que incorrer em violação de segredo profissional, incorrerá na prática do crime previsto no artigo 154 do Código Penal, in verbis:

Art. 154. Revelar alguém, sem justa causa, segredo, de quem tem ciência em razão de função, ministério, oficio ou profissão, e cuja revelação possa produzir dano a outrem. (grifou-se).

Pena detenção, de 3 (três) meses a I (um) ano, ou multa.

A expressão 'possa produzir dano' mostra que deve haver a probahilidade de dano (moral ou patrimonial) a terceiro caso contrário, não existirá conduta punível.

Assim, bastará o dano potencial para que o médico incida na conduta tipificada no Código Penal, o mesmo não ocorrendo com relação ao dano pessoal, que depende de efetiva violação da intimidade do empregado-paciente. 
A questão assume relevância, pois, pode se manifestar de diversas formas no curso do contrato de trabalho.

Determinado empregado, pode ser discriminado por colegas, em virtude de uma indevida divulgação do resultado de exame, onde se constatou a existência de determinada doença não transmissivel, feita propositadamente, como forma de forçá-lo a pedir demissão do emprego.

\section{b) Da discriminação em virtude de doença}

Existem doenças que, em virtude da gravidade ou da ignorância popular. trazem grande dose de discriminação por parte das pessoas. como ocorreu com a tuberculose, lepra, sifilis e, mais recentemente, com a AIDS.

Sendo o empregado, geralmente, pessoa leiga, a simples divulgação de que determinada pessoa da empresa é portadora de tais doenças, já é suficiente para gerar anseio, dúvida e discriminação no local de trabalho.

No caso específico da AIDS, enquanto cientificamente ficar comprovado que a transmissão se faz por três modos: via relação sexual, via endovenosa e parietal, nem o portador de HIV. nem o afetado por doença oportunística pode ser discriminado no emprego.

A questão é bastante complexa, porém, entende-se que poderá configurarse o dano pessoal, se restar demonstrado que a não-contratação ou a demissão, ocorreu por motivo da moléstia em momento que o candidato ou o empregado poderia perfeitamente trabalhar.

O mesmo não ocorrerá, porém, se ficar demonstrado que determinada doença é transmissível pela simples convivência social: impõe-se a preservação da saúde dos demais empregados e clientes, ressalvada a obrigação de comunicação às autoridades públicas. Ainda, dentro desta hipótese, o médico informa qui o candidato encontra-se inapto à função que se destina e se já for empregado (exame periódico), não mais terá condições de continuar trabalhando, sempre, porém, ocultando o diagnóstico, exceto para o paciente, que é dono do mesmo.

À medida que a doença se alastra, os ordenamentos têm-se preocupado, em estabelecer critérios para seu tratamento jurídico.

Algumas normas coletivas têm previsão de garantia de emprego aos empregados portadores de AIDS, sem qualquer ressalva.

Acórdãos já têm sido proferidos, entendendo que a dispensa em virtude de AIDS, além de discriminatória, seria obstativa ao dircito de tratamento pela previdência 
social, outros entendem, que o portador de tal doença, teria direito à estabilidade, como o mencionado por Alice Monteiro de Barros, in verbis:

\begin{abstract}
Mandado de Segurança. Sendo o empregado portador de doença que pode levá-lo à morte, estando prestes a adquirir o direito à estabilidade no emprego, havendo sido demitido de forma obstativa e sendo absolutamente necessário o exercício de sua atividade profissional no combate ao mal que $o$ aflige, o transcurso do tempo i imprescindivel para que se evite o perecimento de seu direito. O periculum in mora é o próprio risco do perecimento da vida do empregado. De que adiantaria o empregado sagrar-se vencedor numa ação trabalhista após sua morte? O direito deve ser ágil e ser aplicado no momento certo. sob pena de tornar-se inócuo, mormente neste caso concreto, onde mais importante que os eventuais valores monetários $\mathrm{cm}$ discussão é a própria vital necessidade de o empregado exercer suas funções enquanto apto para tal.
\end{abstract}

(TST-RO-MS 110.056/94.5. Rel. Min. Armando de Brito, sessão de 7.3.95, da SDI).

Dessa forma. além da proibição de ocorrência de dispensa discriminatória em virtude da cloença, sendo cabivel a reintegração. como têm entendido nossos Tribunais, o empregador pode ser condenado à reparação dos danos pessoais causados ao empregado se ficar demonstrado que agiu com evidente intuito de causar prejuízo ao mesmo.

Assim, se o portador do virus HIV está capacitado para trabalhar, não há que se falar em dispensa e, se esta por acaso ocorrer, de forma discriminatória, haterá dano pessoal, podendo o empregado pleitear a devida reparação.

\title{
5. Relação de emprego e relação pessoal
}

As duas principais obrigações sinalagmáticas que a relação de emprego implica (prestar serviço de modo subordinado e pagamento), levaram autores a afirmar, que ela comporta, apenas, uma relação patrimonial.

Não se pode negar que esta seja importante, mas a relação empregaticia cria, lambím, uma inter-subjetividade entre empregado e empregador. scja este pessoa física ou jurídica. Se ela não existisse, ter-se-ia quc apelar, como de fato se fez, para uma relação essencial e juridicamente diversa. para explicar o dano pessoal entre empregado e empregador.

Como conclusão, é importante que se frise, que há uma relação intersubjetiva entre empregado e empregador muito acentuada, que dá oportunidade, pelo 
trato sucessivo da relação, a uma das partes (e até a ambas), de uma violar a privacidade da outra ou, ainda, da violação acontecer reciprocamente.

\section{Conclusão}

Seria negar o velho ditado, segundo o qual, "nil novi sub sole". dizer que a violação da privacidade só passou a ocorrer nas relações de trabalho nos últimos anos, mais precisamente após 1988. com a promulgação da atual Constituição Federal.

$\mathrm{O}$ que efetivamente novo ocorreu e que merece destaque, é a duplicidade de indenizações que um mesmo ato pode provocar. Toma-se, propositadamente, o exemplo da ofensa à privacidade da pessoa humana no ambiente de trabalho, antes de voltar a atenção para o dano pessoal específico que ela comportava, se vítima o empregador, este tinha direito, apenas, ao não-pagamento da indenização de antigüidade ou da multa fundiária; se vítima o empregado, este tinha direito ao recebimento de uma indenização de antigüidade depois de um ano de serviço ou da multa fundiária, quantias que, conforme o tempo de serviço, podiam ser de pequeno valor.

Hoje. concebe-se a exigência de uma reparação essencialmente diferente para tal violação da privacidade, por meio de ação de indenização pelo dano pessoal.

Há o direito, sem incidir em "bis in idem" a uma outra indenização trabalhista decorrente de uma responsabilidade materialmente trabalhista, cujo montante obedece a critérios diversos da indenização tarifada.

Reconhece-se, todavia, que a quantificação da reparação em dinheiro tem peculiaridades no âmbito das relações, porque, embora afastando a impunidade, deve ser levado em conta, que as condições econômicas das partes não são simétricas.

E o fato mais relevante de todo o raciocínio supra desenvolvido é o de que todo empregado deve ser respeitado como cidadão.

São Paulo, maio de 2005. 